ISSN 2623-6575

GLASILO

UDK 631

UDK 630

UDK 502.1

FUTURE

UDK 008
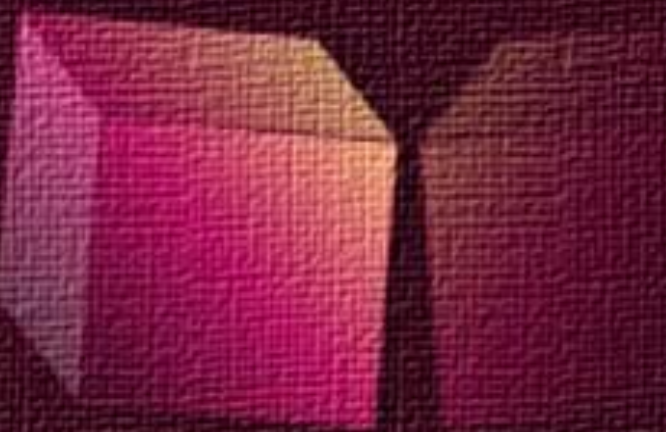

VOLUMEN 1 BROJ 3

KOLOVOZ 2018. 


\section{Glasilo Future}

\section{Stručno-znanstveni časopis}

Nakladnik:

FUTURA

\section{FUTUR}

Sjedište udruge: Šibenik

\section{Adresa uredništva:}

Bana Josipa Jelačića 13 a, 22000 Šibenik, Hrvatska / Croatia

留 / 圆: +385 (0) 022218133

凹: urednistvo@gazette-future.eu / editors@gazette-future.eu

(3): www.gazette-future.eu

\section{Uređivački odbor / Editorial Board:}

Doc. dr. sc. Boris Dorbić, v. pred. - glavni i odgovorni urednik / Editor-in-Chief

Emilija Friganović, dipl. ing. preh. teh., v. pred. - zamjenica g. i o. urednika / Deputy Editor-in-Chief

Ančica Sečan Matijaščić, univ. bacc. act. soc. - tehnička urednica / Technical Editor

Antonia Dorbić, mag. art. - zamjenica tehničke urednice / Deputy Technical Editor

Prof. dr. sc. Željko Španjol

Mr. sc. Milivoj Blažević

Vesna Štibrić, dipl. ing. preh. teh.

\section{Međunarodno uredništvo / International Editorial Board:}

Prof. dr. sc. Kiril Bahcevandziev - Portugal (Instituto Politécnico de Coimbra)

Prof. dr. sc. Martin Bobinac - Srbija (Šumarski fakultet Beograd)

Doc. dr. sc. Zvezda Bogevska - Makedonija (Fakultet za zemjodelski nauki i hrana Skopje)

Dario Bognolo, mag. ing. - Hrvatska (Veleučilište u Rijeci)

Prof. dr. sc. Agata Cieszewska - Poljska (Szkoła Główna Gospodarstwa Wiejskiego w Warszawie)

Prof. dr. Bogdan Cvjetković, prof. emeritus - Hrvatska (Agronomski fakultet Zagreb)

Prof. dr. sc. Duška Ćurić - Hrvatska (Prehrambeno-biotehnološki fakultet Zagreb)

Doc. dr. sc. Margarita Davitkovska - Makedonija (Fakultet za zemjodelski nauki i hrana Skopje)

Doc. dr. sc. Dubravka Dujmović - Hrvatska (Agronomski fakultet Zagreb)

Prof. dr. sc. Semina Hadžiabulić - Bosna i Hercegovina (Agromediteranski fakultet Mostar)

Prof. dr. sc. Péter Honfi - Mađarska (Faculty of Horticultural Science Budapest)

Prof. dr. sc. Valeria Ivanova - Bugarska (Fakultet za lozaro - gradinarstvo Plovdiv)

Doc. dr. sc. Orhan Jašić - Bosna i Hercegovina (Filozofski fakultet Tuzla)

Prof. dr. sc. Biljana Lazović - Crna Gora (Biotehnički fakultet Podgorica)

Hrv. akademik prof. dr. sc. Stanislav Nakić - Bosna i Hercegovina (Sveučilište Hercegovina Mostar)

Sandra Popović, mag. ing. - Srbija (Poljoprivredni fakultet Beograd)

Doc. dr. sc. Bojan Simovski - Makedonija (Šumarski fakultet Skopje)

Prof. dr. sc. Davor Skejić - Hrvatska (Građevinski fakultet Zagreb)

Doc. dr. sc. Milan Stanković - Srbija (Univerzitet u Kragujevcu)

Akademik prof. dr. sc. Refik Šećibović - Bosna i Hercegovina (Visoka škola za turizam i menadžment Konjic)

Prof. dr. sc. Andrej Šušek - Slovenija (Fakulteta za kmetijstvo in biosistemske vede Maribor)

Prof. dr. sc. Elma Temim - Bosna i Hercegovina (Agromediteranski fakultet Mostar)

Doc. dr. sc. Ivana Vitasović Kosić - Hrvatska (Agronomski fakultet Zagreb)

Doc. dr. sc. Ana Vujošević - Srbija (Poljoprivredni fakultet Beograd)

Prof. dr. sc. Vesna Židovec - Hrvatska (Agronomski fakultet Zagreb)

Lektura i grafička priprema: Ančica Sečan Matijaščić, univ. bacc. act. soc.

Objavljeno: 18. kolovoza 2018. godine.

Časopis izlazi u elektroničkom izdanju dva puta godišnje, krajem lipnja i prosinca, a predviđena su i dva

interdisciplinarna specijalna izdanja tijekom godine iz STEM i ostalih znanstvenih/umjetničkih područja.

Časopis je besplatan.

Rukopisi i recenzije se ne vraćaju i ne honoriraju.

Umnožavanje (reproduciranje), stavljanje u promet (distribuiranje), priopćavanje javnosti, stavljanje na raspolaganje javnosti odnosno prerada u bilo kojem obliku nije dopuštena bez pismenog dopuštenja Nakladnika. Sadržaj objavljen u Glasilu Future može se slobodno koristiti u osobne i obrazovne svrhe uz obvezno navođenje izvora. 


\section{Glasilo Future}

\section{Stručno-znanstveni časopis}

FUTURA - stručno-znanstvena udruga za promicanje održivog razvoja, kulture i međunarodne suradnje, Bana Josipa Jelačića 13 a, 22000 Šibenik, Hrvatska

(2018) 1 (3) 01-75

\section{SADRŽAJ:}

Izvorni znanstveni rad (original scientific paper)

Str.

E. Delić, Jasnica Medak, Azra Bakrač, Subha Džafić, B. Dorbić, Berina Muhović

Dendroflora Gradskog parka u Bihaću

Woody Plants in the Bihać City Park

\section{Pregledni rad (scientific review)}

Martina Rubě̌a

Digitalne nejednakosti i potencijal za socijalno uključivanje

Digital Inequalities and Potential for Social Inclusion

Ančica Sečan Matijaščić

Pravo na privatnost i objavljivanje osobnih podataka, informacija (o) i fotografija maloljetne djece

The Right to Privacy and Publishing of Personal Data, Information (about) and

Photographs of Minor Children

\section{Nekategorizirani rad (uncategorised paper)}

Nina Gojić

Prikaz predstave

Play review

\section{B. Dorbić}

Prikaz knjige

Book review

D. Crnogaća, M. Chiabov, Ana Selak

Prikaz radova natječaja

Competition proposals review 


\title{
Dendroflora Gradskog parka u Bihaću
}

\section{Woody Plants in the Bihać City Park}

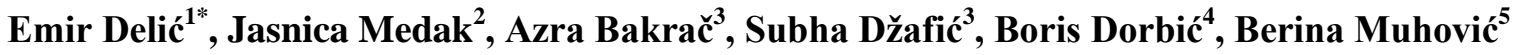 \\ izvorni znanstveni rad (original scientific paper)
}

\section{Sažetak}

U radu su prikazani rezultati istraživanja dendroflore Gradskog parka na području grada Bihaća, koji je smješten u sjeverozapadnom dijelu Bosne i Hercegovine, podno planina Plješevice i Grmeč te brda Debeljača. Kroz njega protječu rijeka Una te njeni pritoci Klokot i Privilica. Tijekom florističkog istraživanja koje je provedeno na obuhvatnom području Gradskog parka u Bihaću, tijekom 2016. godine, zabilježeno je 80 svojti iz 30 porodica, s ukupno 663 jedinke. U parku dominiraju kritosjemenjače (66 svojti; 83 \%), među kojima su dvosupnice (78; 97 \%), u većoj mjeri zastupljenije nego jednosupnice (2; 3 \%). Golosjemenjače su zastupljene s 14 svojti (17\%). S najvećim brojem vrsta ističe se porodica Rosaceae (10 svojti; $13 \%$ ) od ukupno 80 svojti. U pogledu habitusa (Erhardt et al., 2002.) dominiraju stabla (45 svojti; $56 \%$ ), potom slijede grmovi (32 svojte; $40 \%$ ), zatim penjačice (2 svojte; $3 \%)$ i puzavice (1 svojta; $1 \%)$. Listopadne svojte $(60 ; 75 \%)$ su zastupljenije od vazdazelenih $(19 ; 24 \%)$ i zimzelenih $(1 ; 1 \%)$. Najbrojnija svojta u parku je hibridna platana (Platanus $x$ hispanica Münch) sa 115 jedinki. Prema geografskom podrijetlu alohtone svojte $(42 ; 52 \%)$ su zastupljenije od autohtonih $(35 ; 44 \%)$ i hibrida $(3 ; 4 \%)$. Od 42 determinirane alohtone svojte u invazivne spadaju tri (7\%), dok u egzote spada 39 svojti (93 \%). Od 80 zabilježenih svojti, u kultivare spada 15 svojti (19\%), a u hibride tri svojte (4\%). U pogledu krajobraznih vrijednosti Gradski park u Bihaću, koji je izgrađen 1888. godine, veoma je bogat dendrološkim svojtama. Neke od njih potječu iz vremena podizanja parka. Navedeni objekt se ubraja u ljepše bosanskohercegovačke parkove. Međutim potrebna mu je dodatna revitalizacija. Drveće i grmlje uglavnom ima dobre funkcionalne, estetske i oblikovne karakteristike. Parkovna infrastruktura je u vrlo dobrom stanju.

Ključne riječi: dendroflora, inventarizacija, opis stanja, Bihać, Gradski park, svojte.

\footnotetext{
${ }^{1}$ Emir Delić, BA šumarstva, pred., 501. Slavne Brigade 71, 77000 Bihać, Bosna i Hercegovina.

* Email: emir.delicc@outlook.com.

${ }^{2}$ Dr. sc. Jasnica Medak, Hrvatski šumarski institut, Cvjetno naselje 41, 10450 Jastrebarsko, Hrvatska.

3 Prof. dr. sc. Azra Bakrač, Subha Džafić, mag. ing. biol., Univerzitet u Bihaću, Biotehnički fakultet, Luke Marjanovića bb, 77000 Bihać, Bosna i Hercegovina.

4 Doc. dr. sc. Boris Dorbić, v. pred., Veleučilište "Marko Marulić" u Kninu, Odjel Poljoprivreda krša, Krešimirova 30, 22300 Knin, Hrvatska.

${ }^{5}$ Berina Muhović, BA gen. i bioing, Fra Matije Divkovića 12, 71000 Sarajevo, Bosna i Hercegovina.
} 


\section{Abstract}

The paper presents the findings of a research on woody plants in the city park of the city of Bihać, located in the north-western part of Bosnia and Herzegovina, under the mountains Plješevica and Grmeč, as well as under Debeljača hill. The Una River and its tributaries Klokot and Privilica flow through the city. Throughout the floristic research study conducted in the area covered by the city park in Bihać, in 2016, 80 plant species from 30 families were identified, comprising of a total of 663 individual plants. Angiospermae (66 species; $83 \%$ ) are the most dominant in the park, among which Dicotyledonae $(78 ; 97 \%)$ were identified, which have a significantly greater share compared with Monocotyledonae (2; 3\%). There are 14 species of Gymnospermae (17\%). Rosaceae family stands out with the largest number of species (10 species; 13\%) of a total 80 plant species. Concerning the growth form (according to Erhardt et al., 2002) trees are dominant (45 species; 56\%), followed by shrubs (32 species; 40\%), climbers ( 2 species; 3\%) and creepers (1 species; 1\%). Deciduous species $(60 ; 75 \%)$ have a higher share compared with evergreens $(19 ; 24 \%)$ and conifers $(1 ; 1 \%)$. The most widespread species in the park is a hybrid plane species (Platanus $x$ hispanica Münch) with 115 trees. According to geographical origin, allochthonous species $(42 ; 52 \%)$ are more widespread in relation to autochthonous species $(35 ; 44 \%)$ and hybrids $(3 ; 4 \%)$. Out of 42 identified allochthonous species, 3 are invasive species (7\%), while there are 39 species (93\%) of exotic plants. Out of 80 identified species, 15 species (19\%) are cultivars, while 3 species (4\%) are hybrids. Concerning the landscape value, the City Park in Bihać, established in 1888, abounds in woody species. Some of them trace their origins back to the time the park was being established. The Park facility in question is considered amongst the most beautiful parks in Bosnia and Herzegovina. Nevertheless, further revitalisation is required. Trees and shrubs are in general provided with good functional, aesthetic and design features. Park infrastructure is in very good condition.

Key words: woody plants, inventory, description of the situation, Bihać, City Park, plant species.

\section{Uvod}

Nastanak prvih javnih parkovnih površina u Bosni i Hercegovini datira od nastanka ugovora o zaštiti zelenih površina grada Sarajeva iz 1885. godine, a sklopila ga je Zemaljska vlada BiH s Vakufskim vijećem. U to vrijeme su u Sarajevu formirana tri javna parka ukupne površine $40.000 \mathrm{~m}^{2}$ (Veliki park i Mali park, Park cara Dušana te Zeleni trg iza zgrade Izvršnog vijeća) (Ljujić-Mijatović et al., 2010).

Usporedno s gore navedenim, kod formiranja mostarskih parkova nisu primjenjivane međunarodne konvencije o zaštiti povijesnih parkova te su smjernice dane za sarajevske parkove primijenjene i na parkove Mostara. Istraživanjima bosansko-hercegovačke flore bavili su se mnogi naši i strani autori: Dr. Günther Beck, K. Vandas, Franz Fiala, Dr. Arpad von Degen, Karl Maly, Nikola Janjć (Ljujić Mijatović et al., 2010). 
Austrougarska vojska je 1878. godine u Bosni i Hercegovini zauzela i Bihać te nova uprava gradi i otvara javne te kulturne ustanove. Godine 1888. srušene su zidine tvrđave i napravljene su nove ulice. Ova godina je značajna po tome jer se uređuje i Gradski park u centru Bihaća (Bihać kroz vrijeme, 2010). ${ }^{6}$

U Gradskom parku prevladavaju stabla, od kojih su najimpozantnije hibridne platane (Platanus $x$ hispanica Münch), one datiraju još iz doba austrougarske uprave, kao i stabla divljeg kestena (Aesculus hippocastanum L.). Godine 2010. japanska nevladina organizacija "Ipil-ipil-no-kai" donirala je sadnice japanskih trešanja (Prunus serrulata "Kanzan") kojima je uz novoizgrađenu šetnicu formiran jednostrani drvored koji je izrazito atraktivan u proljeće (Natura Jadera, 2014). ${ }^{7}$

Istraživanje dendroflore kontinentalnog područja susjednih zemalja, Hrvatske uglavnom je vezano za popisivanje svojti u pojedinim parkovnim objektima (Karavla 2006; Mlinar i Trošić 2004; Poljak et al., 2011). Nadalje, Rauš (1969) analizira zastupljenost autohtonih i alohtonih vrsta u Vukovarskim parkovima. O zaštićenim spomenicima parkovne arhitekture pisali su Španjol et al. (2011). Židovec i Karlović (2005) pojašnjavaju razloge uporabe autohtone dendroflore prilikom uređenja zelenih površina.

Mlinar i Trošić (2004) u radu vezanom za inventarizaciju i valorizaciju parkova zagrebačkih stambenih naselja izgrađenih između dva svjetska rata na istraživanom području koje je obuhvaćalo 15 stambenih naselja zabilježili su ukupno 68 taksona (vrsta i kultivara) i to 11 golosjemenjača i 57 kritosjemenjača.

Na području Bosne i Hercegovine, točnije Banja luke, Stupar (2009) za park "Univerzitetski grad" u Banjoj Luci navodi da su u navedenom objektu evidentirana ukupno 88 taksona, s 1533 primjerka, što ga čini veoma bogatim objektom gradskog zelenila. Na ovom lokalitetu najviše je stabala (88\%) alohtonih vrsta koje dolaze iz Sjeverne Amerike.

Prilikom projektiranja i oblikovanja parkova i zelenih površina treba voditi računa i o otrovnim te alergenim vrstama. Posebno se to odnosi na površine oblikovane u prethodnom političkom sustavu. Na važnost ove problematike ukazuju Vlahović i Karlović (2013) koje su u florističkom istraživanju okoliša dječjih vrtića i škola evidentirale 182 primjerka otrovnih i 129 primjerka alergenih biljaka. Kao najzastupljeniju otrovnu vrstu navode šimšir (Buxus sempervirens L.), a najzastupljenija alergena vrsta bila je breza (Betula pendula Roth).

\footnotetext{
${ }^{6}$ Gradski park podrazumijeva javnu zelenu (krajobraznu) površinu koja se nalazi u okviru užeg urbanog područja, veličine preko 2 ha i kao takva služi za odmor, šetnju i igru. Parkovi utječu na izgled i strukturu urbanih sredina, omogućuju biološku raznolikost $i$ čine gradove te urbana naselja ugodnijim i ljepšim mjestima za život (Čomić et al., 2009). Parkovi i zeleni površine imaju i značajnu socijalnu (društvenu) ulogu u urbanim sredinama (Dorbić i Temim, 2014).

${ }^{7}$ Prunus serrulata "Kanzan" - korigirao po izvorniku, Delić, 2016.
} 
Grad Bihać je smješten u sjeverozapadnom dijelu Bosne i Hercegovine i gospodarsko je, administrativno i kulturno središte Unsko-sanskog kantona s ukupnom površinom od $900 \mathrm{~km}^{2}$. Reljef bihaćke općine većinom se sastoji od polja, brežuljaka i planina srednje visine. Velik dio bihaćke općine bogat je izvorima, potocima, rijekama i podzemnim vodama. Kroz Bihać protječu rijeka Una i njene pritoke Klokot i Privilica. Klima je uglavnom umjereno-kontinentalna i umjereno-planinska, uz male promjene zbog zračnih masa. Ljeta su vrlo topla i suha, uz rijetke kratke ili duge pljuskove, a zime hladne s dosta oborina većinom kišnih. Godišnji prosjek oborina iznosi 13271/ $\mathrm{m}^{2}$, a prosječna mjesečna temperatura je $10,8{ }^{\circ} \mathrm{C}$ (Anonymous, 2016).

U gradu Bihaću se za krajobrazno uređenje parkova i zelenih površina uglavnom koriste kontinentalne (mezofilne i higrofilne) dendrološke svojte.

\section{Materijali i metode}

U radu je inventarizirana dendroflora na području Gradskog parka u Bihaću (Slika 1.). Tijekom terenskih istraživanja od siječnja do prosinca mjeseca 2016. godine inventarizirano je 80 dendroloških svojti. Istraživanja su se zasnivala na obilasku terena, opisivanju istraživane površine metodom promatranja, utvrđivanju brojnosti dendroloških svojti i inventarizaciji dendroflore. Površina Gradskog parka iznosi 3,1 ha, te ovaj park po obliku, izgledu, svojtama i vrijednosti predstavlja najvrjedniju i najznačajniju javnu zelenu (krajobraznu) površinu u gradu. Kako je prethodno navedeno, jedan je od ljepših BIH parkova, a izgrađen je za vrijeme austrougarske uprave u Bosni i Hercegovini, davne 1888. godine. Brigu oko održavanja vodi "Javno komunalno preduzeće Komrad Bihać".

Za determinaciju biljnih vrsta korištena je sljedeća floristička literatura: Tutin et al., 1964-1980; Walters et al., 1986; Walters et al., 1989; Domac, 1994; Erhardt et al., 2002; Vidaković i Franjić, 2004; Idžojtić, 2005; Idžojtić, 2009; Idžojtić, 2013; Šilić, 1990; Šilić, 2005.

Nomenklatura svojti u popisu flore usklađena je prema Nikoliću (2012).

Hrvatski nazivi svojti dani su prema: Domac (1994); Vidaković i Franjić (2004); Idžojtić (2009).

U popisu flore, vrste i podvrste su navedene abecednim redom u okviru porodica i viših sistematskih kategorija. Za svaku svojtu navedeno je sljedeće: oblik habitusa, znanstveno ime, oznaka radi li se o domaćoj (autohtonoj) ili stranoj (alohtonoj) svojti (Tablica 1.).

Razdioba životnih oblika dana je prema Erhardtu et al. (2002) uz određena pojednostavljenja, a u popisu flore navode se sljedeće kratice: G-grm, G/S-grm ili stablo, S/G-stablo ili grm, S-stablo, Li-penjačica (lijana), Pu-puzavica. 
Raspodjela svojti na listopadne (L), zimzelene (Z) i vazdazelene (V) preuzeta je iz: Walters (1986); Walters (1989); Erhardt et al. (2002).

Dendroflora Gradskog parka u Bihaću je, s obzirom na podrijetlo svojti, razvrstana na autohtone ili alohtone svojte, kultivare (K), hibride (H), egzote (E) i invazivne (I) vrste (Redžić et al., 2008).

Razvrstavanje dendroflore $\mathrm{u}$ navedene kategorije obavljeno je prema utvrđenom stanju na istraživanom području.

Slika 1. Satelitska snimka istraživanog područja na području Gradskog parka u Bihaću (Natura Jadera, 2014).

Figure 1. Satellite image of the investigated area in Bihać City park (Natura Jadera, 2014).

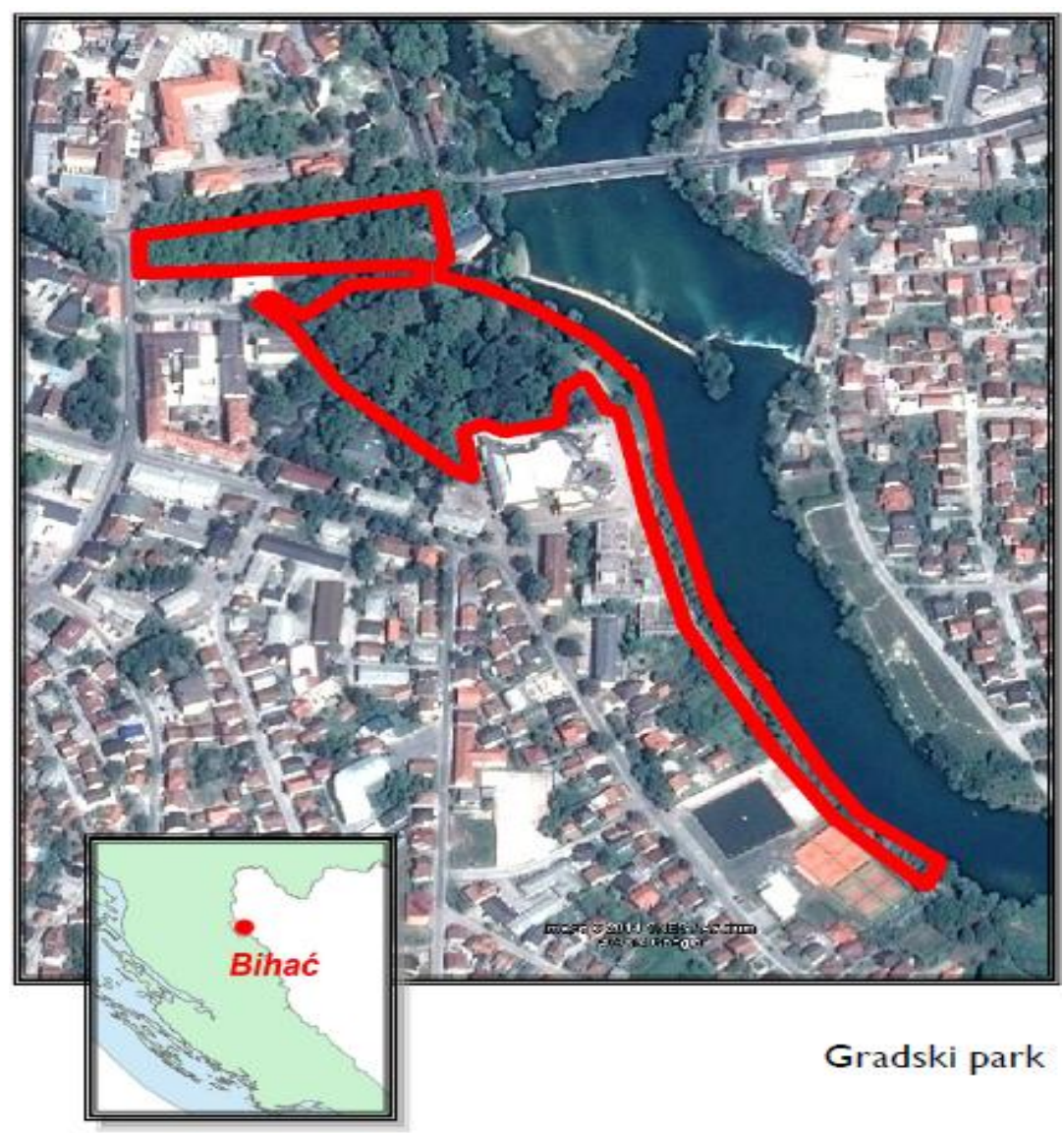

\section{Rezultati istraživanja}

\section{Popis flore}

Popis dendroflore Gradskog parka u Bihaću dan je u Tablici 1. Dendroflora u parku je determinirana do razine kultivara s ukupno 80 svojti i 663 jedinke. U tablici je dan i brojčani prikaz svake prisutne jedinke određene svojte. 
Tablica 1. Popis dendroflore u istraživanom području Gradskog parka u Bihaću (Delić, 2016).

Table 1. List of dendroflora in the investigation area of Bihać City par (Delić, 2016).

\begin{tabular}{|c|c|c|c|c|c|c|}
\hline \multicolumn{6}{|c|}{ SPERMATOPHYTA / GYMNOSPERMAE / CONIFEROPSIDA } & \multirow{2}{*}{$\begin{array}{c}\text { kom } \\
2\end{array}$} \\
\hline $\begin{array}{l}\text { Abies alba Mill. } \\
\text { (Obična jela) }\end{array}$ & Pinaceae & $\mathrm{S}$ & $\mathrm{V}$ & Autohtona & & \\
\hline $\begin{array}{l}\text { Cedrus atlantica "Glauca" } \\
\text { (Atlaski cedar) }\end{array}$ & Pinaceae & $\mathrm{S}$ & $\mathrm{V}$ & Alohtona & $\mathrm{E}$ & 1 \\
\hline $\begin{array}{l}\text { Chamaecyparis lawsoniana } \\
\text { (A.Murray) Parl. } \\
\text { (Lavsonov pačempres) }\end{array}$ & Cupressaceae & $\mathrm{S}$ & $\mathrm{V}$ & Alohtona & $\mathrm{E}$ & 20 \\
\hline $\begin{array}{l}\text { Chamaecyparis lawsoniana "Alumii" } \\
\text { (Lavsonov pačempres) }\end{array}$ & Cupressaceae & $\mathrm{S}$ & $\mathrm{V}$ & Alohtona $(\mathrm{K})$ & $\mathrm{E}$ & 9 \\
\hline $\begin{array}{l}\text { Juniperus chinensis "Hetzii" } \\
\text { (Kineska borovica) }\end{array}$ & Cupressaceae & G & $\mathrm{V}$ & Alohtona $(\mathrm{K})$ & $\mathrm{E}$ & 4 \\
\hline $\begin{array}{l}\text { Juniperus communis } \mathrm{L} . \\
\text { (Obična borovica) }\end{array}$ & Cupressaceae & $\mathrm{S}$ & $\mathrm{V}$ & Autohtona & & 1 \\
\hline $\begin{array}{l}\text { Picea abies (L.) H. Karst. } \\
\text { (Obična smreka) }\end{array}$ & Pinaceae & $\mathrm{S}$ & $\mathrm{V}$ & Autohtona & & 26 \\
\hline $\begin{array}{l}\text { Picea omorika (Pančić) Purk. } \\
\text { (Pančićeva omorika) }\end{array}$ & Pinaceae & $\mathrm{S}$ & $\mathrm{V}$ & Autohtona & & 17 \\
\hline $\begin{array}{l}\text { Picea pungens Engelm. } \\
\text { (Bodljikava smrča) }\end{array}$ & Pinaceae & $\mathrm{S}$ & $\mathrm{V}$ & Alohtona & $\mathrm{E}$ & 5 \\
\hline $\begin{array}{l}\text { Pinus nigra J. F. Arnold } \\
\text { (Crni bor) }\end{array}$ & Pinaceae & $\mathrm{S}$ & $\mathrm{V}$ & Autohtona & & 5 \\
\hline $\begin{array}{l}\text { Platycladus orientalis (L.) Franco } \\
\text { (Istočna tuja) }\end{array}$ & Cupressaceae & $\mathrm{G} / \mathrm{S}$ & $\mathrm{V}$ & Alohtona & $\mathrm{E}$ & 8 \\
\hline $\begin{array}{l}\text { Taxodium distichum (L.) Rich. } \\
\text { (Močvarni taksodij) }\end{array}$ & Taxodiaceae & $\mathrm{S}$ & $\mathrm{L}$ & Alohtona & $\mathrm{E}$ & 1 \\
\hline $\begin{array}{l}\text { Taxus baccata } \mathrm{L} . \\
\text { (Obična tisa) }\end{array}$ & Taxaceae & $\mathrm{S}$ & $\mathrm{V}$ & Autohtona & & 14 \\
\hline $\begin{array}{l}\text { Thuja occidentalis } \mathrm{L} . \\
\text { (Američka tuja) }\end{array}$ & Cupressaceae & $\mathrm{G} / \mathrm{S}$ & $\mathrm{V}$ & Alohtona & $\mathrm{E}$ & 7 \\
\hline \multicolumn{6}{|c|}{ ANGIOSPERMAE / MAGNOLIOPSIDA (DICOTYLEDONES) } & kom \\
\hline $\begin{array}{l}\text { Acer campestre } \mathrm{L} . \\
\text { (Javor klen) }\end{array}$ & Aceraceae & $\mathrm{S}$ & $\mathrm{L}$ & Autohtona & & 1 \\
\hline $\begin{array}{l}\text { Acer negundo } \mathrm{L} . \\
\text { (Javor pajavac) }\end{array}$ & Aceraceae & $\mathrm{S}$ & $\mathrm{L}$ & Alohtona & I & 21 \\
\hline $\begin{array}{l}\text { Acer platanoides } \mathrm{L} \text {. } \\
\text { (Javor mliječ) }\end{array}$ & Aceraceae & $\mathrm{S}$ & $\mathrm{L}$ & Autohtona & & 6 \\
\hline $\begin{array}{l}\text { Acer pseudoplatanus } \mathrm{L} . \\
\text { (Gorski javor) }\end{array}$ & Aceraceae & $\mathrm{S}$ & $\mathrm{L}$ & Autohtona & & 33 \\
\hline $\begin{array}{l}\text { Acer saccharinum } \mathrm{L} \\
\text { (Srebrnolisni javor) }\end{array}$ & Aceraceae & $\mathrm{S}$ & $\mathrm{L}$ & Alohtona & $\mathrm{E}$ & 2 \\
\hline $\begin{array}{l}\text { Acer ginnala (Maxim.) Wesm. } \\
\text { (Kineski javor) }\end{array}$ & Aceraceae & $\mathrm{S}$ & $\mathrm{L}$ & Alohtona & $\mathrm{E}$ & 10 \\
\hline $\begin{array}{l}\text { Aesculus hippocastanum } \mathrm{L} . \\
\text { (Obični divlji kesten) }\end{array}$ & Hippocastanaceae & $\mathrm{S}$ & $\mathrm{L}$ & Autohtona & & 12 \\
\hline $\begin{array}{l}\begin{array}{l}\text { Ailanthus altissima (Mill.) Swingle } \\
\text { (Pajasen) }\end{array} \\
\end{array}$ & Sapindaceae & $\mathrm{S}$ & $\mathrm{L}$ & Alohtona & I & 1 \\
\hline $\begin{array}{l}\text { Alnus glutinosa (L.) Gaertn. } \\
\text { (Crna joha) }\end{array}$ & Betulaceae & $\mathrm{S}$ & $\mathrm{L}$ & Autohtona & & 4 \\
\hline $\begin{array}{l}\text { Berberis julianae C. K. Schneid. } \\
\text { (Julijanina žutika) }\end{array}$ & Berberidaceae & $\mathrm{G}$ & $\mathrm{V}$ & Alohtona & $\mathrm{E}$ & 1 \\
\hline $\begin{array}{l}\text { Berberis thunbergii DC. } \\
\text { (Thunbergova žutika) }\end{array}$ & Berberidaceae & G & $\mathrm{L}$ & Alohtona & $\mathrm{E}$ & 6 \\
\hline $\begin{array}{l}\text { Berberis thunbergii "Atropurpurea" } \\
\text { (Thunbergova žutika) }\end{array}$ & Berberidaceae & G & $\mathrm{L}$ & Alohtona & $\mathrm{E}$ & 1 \\
\hline
\end{tabular}


E. Delić, Jasnica Medak, Azra Bakrač, Subha Džafić, B. Dorbić, Berina Muhović / Dendroflora Gradskog parka u Bihaću / Glasilo Future (2018) 1 (3) 01-14

\begin{tabular}{|c|c|c|c|c|c|c|}
\hline $\begin{array}{l}\text { Betula papyrifera Marshall } \\
\text { (Papirna breza) }\end{array}$ & Betulaceae & S & $\mathrm{L}$ & Alohtona & $\mathrm{E}$ & 1 \\
\hline $\begin{array}{l}\text { Betula pendula Roth } \\
\text { (Obična breza) }\end{array}$ & Betulaceae & S & $\mathrm{L}$ & Autohtona & & 21 \\
\hline $\begin{array}{l}\text { Carpinus betulus } \mathrm{L} . \\
\text { (Obični grab) }\end{array}$ & Betulaceae & $S$ & $\mathrm{~L}$ & Autohtona & & 3 \\
\hline $\begin{array}{l}\text { Catalpa bignonioides Walter } \\
\text { (Obična katalpa) }\end{array}$ & Bignoniaceae & $S$ & $\mathrm{~L}$ & Alohtona & $\mathrm{E}$ & 13 \\
\hline $\begin{array}{l}\text { Chaenomeles speciosa (Sweet) Nakai } \\
\text { (Kineska dunja) }\end{array}$ & Rosaceae & G & $\mathrm{L}$ & Alohtona & $\mathrm{E}$ & 1 \\
\hline $\begin{array}{l}\text { Cornus mas L. } \\
\text { (Drijen) }\end{array}$ & Cornaceae & $\mathrm{G} / \mathrm{S}$ & $\mathrm{L}$ & Autohtona & & 1 \\
\hline $\begin{array}{l}\text { Corylus avellana } \mathrm{L} . \\
\text { (Obična lijeska) }\end{array}$ & Betulaceae & $\mathrm{G}$ & $\mathrm{L}$ & Autohtona & & 2 \\
\hline $\begin{array}{l}\text { Crataegus monogyna Jacq. } \\
\text { (Jednosjemeni glog) }\end{array}$ & Rosaceae & $\mathrm{G}$ & $\mathrm{L}$ & Autohtona & & 1 \\
\hline $\begin{array}{l}\text { Deutzia scabra "Candidissima" } \\
\text { (Hrapava deucija) }\end{array}$ & Hydrangeaceae & G & $\mathrm{L}$ & Alohtona & $\mathrm{E}$ & 5 \\
\hline $\begin{array}{l}\text { Fagus sylvatica } \mathrm{L} \text {. } \\
\text { (Obična bukva) }\end{array}$ & Fagaceae & $\mathrm{S}$ & $\mathrm{L}$ & Autohtona & & 1 \\
\hline $\begin{array}{l}\text { Forsythia suspensa (Thunb.) Vahl } \\
\text { (Viseća forsitija) }\end{array}$ & Oleaceae & $\mathrm{G}$ & $\mathrm{L}$ & Alohtona & $\mathrm{E}$ & 16 \\
\hline $\begin{array}{l}\text { Fraxinus excelsior } \mathrm{L} . \\
\text { (Europski bijeli jasen) }\end{array}$ & Oleaceae & $S$ & $\mathrm{~L}$ & Autohtona & & 29 \\
\hline $\begin{array}{l}\text { Hedera helix } \mathrm{L} . \\
\text { (Obični bršljan) }\end{array}$ & Araliaceae & $\mathrm{Li}$ & $\mathrm{V}$ & Autohtona & & 7 \\
\hline $\begin{array}{l}\text { Hibiscus syriacus "Oiseau Bleu" } \\
\text { ("Blue Bird") } \\
\text { (Obični hibisk) }\end{array}$ & Malvaceae & $\mathrm{G}$ & $\mathrm{L}$ & Alohtona & $\mathrm{E}$ & 2 \\
\hline $\begin{array}{l}\text { Hibiscus syriacus "Red Heart" } \\
\text { (Obični hibisk) }\end{array}$ & Malvaceae & $\mathrm{G}$ & $\mathrm{L}$ & Alohtona & $\mathrm{E}$ & 2 \\
\hline $\begin{array}{l}\text { Hydrangea arborescens } \\
\text { "Annabelle" } \\
\text { (Drvolika hortenzija) }\end{array}$ & Hydrangeaceae & $\mathrm{G}$ & $\mathrm{L}$ & Alohtona & $\mathrm{E}$ & 1 \\
\hline $\begin{array}{l}\text { Juglans nigra L. } \\
\text { (Američki crni orah) }\end{array}$ & Juglandaceae & $S$ & $\mathrm{~L}$ & Alohtona & $\mathrm{E}$ & 6 \\
\hline $\begin{array}{l}\text { Juglans regia } \mathrm{L} . \\
\text { (Obični orah) }\end{array}$ & Juglandaceae & S & $\mathrm{L}$ & Autohtona & & 1 \\
\hline $\begin{array}{l}\text { Koelreuteria paniculata Laxm. } \\
\text { (Kelreuterija) }\end{array}$ & Sapindaceae & $\mathrm{S}$ & $\mathrm{L}$ & Alohtona & $\mathrm{E}$ & 5 \\
\hline $\begin{array}{l}\text { Lagerstroemia indica "Alba" } \\
\text { (Lagerstremija) }\end{array}$ & Lythraceae & $\mathrm{G}$ & $\mathrm{L}$ & Alohtona & $\mathrm{E}$ & 1 \\
\hline $\begin{array}{l}\text { Ligustrum ovalifolium Hassk. } \\
\text { (Japanska malolisna kalina) }\end{array}$ & Oleaceae & $\mathrm{G}$ & $\mathrm{V}$ & Alohtona & $\mathrm{E}$ & 2 \\
\hline $\begin{array}{l}\text { Liriodendron chinense (Hemsl.) } \\
\text { Sarg. } \\
\text { (Kineski tulipanovac) }\end{array}$ & Magnoliaceae & $S$ & $\mathrm{~L}$ & Alohtona & $\mathrm{E}$ & 1 \\
\hline $\begin{array}{l}\text { Lonicera fragrantissima Lindl. et } \\
\text { Paxton } \\
\text { (Mirisna kozokrvina) }\end{array}$ & Caprifoliaceae & $\mathrm{Li}$ & $\mathrm{Z}$ & Alohtona & $\mathrm{E}$ & 1 \\
\hline $\begin{array}{l}\text { Lonicera nitida } \text { E. H. Wilson } \\
\text { (Sjajna kozokrvina) }\end{array}$ & Caprifoliaceae & G & $\mathrm{V}$ & Alohtona & $\mathrm{E}$ & 6 \\
\hline $\begin{array}{l}\text { Magnolia } x \text { soulangeana Soul.-Bod. } \\
\text { (Soulangeova magnolija) }\end{array}$ & Magnoliaceae & $\mathrm{G}$ & $\mathrm{L}$ & Hibrid & & 5 \\
\hline $\begin{array}{l}\text { Mahonia aquifolium (Pursh) } \\
\text { Nutt. } \\
\text { (Obična mahonija) }\end{array}$ & Berberidaceae & $\mathrm{G}$ & $\mathrm{V}$ & Alohtona & $\mathrm{E}$ & 14 \\
\hline $\begin{array}{l}\text { Malus domestica Borkh. } \\
\text { (Pitoma jabuka) }\end{array}$ & Rosaceae & S & $\mathrm{L}$ & Autohtona & & 1 \\
\hline
\end{tabular}


E. Delić, Jasnica Medak, Azra Bakrač, Subha Džafić, B. Dorbić, Berina Muhović / Dendroflora Gradskog parka u Bihaću / Glasilo Future (2018) 1 (3) 01-14

\begin{tabular}{|c|c|c|c|c|c|c|}
\hline $\begin{array}{l}\text { Platanus x hispanica Münchh. } \\
\text { (Javorolisni platan) }\end{array}$ & Platanaceae & $\mathrm{S}$ & $\mathrm{L}$ & Hibrid & & 115 \\
\hline $\begin{array}{l}\text { Populus nigra } \mathrm{L} . \\
\text { (Europska crna topola) }\end{array}$ & Salicaceae & S & $\mathrm{L}$ & Autohtona & & 1 \\
\hline $\begin{array}{l}\text { Prunus cerasifera "Atropurpurea" } \\
\text { (Džanarika) }\end{array}$ & Rosaceae & $\mathrm{S}$ & $\mathrm{L}$ & Autohtona & & 1 \\
\hline $\begin{array}{l}\text { Prunus laurocerasus } \mathrm{L} . \\
\text { (Lovorvišnja) }\end{array}$ & Rosaceae & G & $\mathrm{V}$ & Alohtona & & 16 \\
\hline $\begin{array}{l}\text { Prunus serrulata "Kanzan" } \\
\text { (Japanska trešnja) }\end{array}$ & Rosaceae & S & $\mathrm{L}$ & Alohtona & $\mathrm{E}$ & 9 \\
\hline $\begin{array}{l}\text { Quercus robur } \mathrm{L} . \\
\text { (Hrast lužnjak) }\end{array}$ & Fagaceae & $\mathrm{S}$ & $\mathrm{L}$ & Autohtona & & 4 \\
\hline $\begin{array}{l}\text { Rhus typhina } \mathrm{L} \text {. } \\
\text { (Kiseli ruj) }\end{array}$ & Anacardiaceae & G & $\mathrm{L}$ & Alohtona & $\mathrm{E}$ & 1 \\
\hline $\begin{array}{l}\text { Robinia pseudoacacia } \mathrm{L} \text {. } \\
\text { (Obični bagrem) }\end{array}$ & Fabaceae & $\mathrm{S}$ & $\mathrm{L}$ & Alohtona & I & 5 \\
\hline Rosa "Iceberg" & Rosaceae & $\mathrm{G}$ & $\mathrm{L}$ & Alohtona (K) & $\mathrm{E}$ & 1 \\
\hline Rosa "Bonica 82" & Rosaceae & $\mathrm{G}$ & $\mathrm{L}$ & Alohtona $(\mathrm{K})$ & $\mathrm{E}$ & 3 \\
\hline $\begin{array}{l}\text { Salix alba } \mathrm{L} . \\
\text { (Bijela vrba) }\end{array}$ & Salicaceae & S & $\mathrm{L}$ & Autohtona & & 25 \\
\hline $\begin{array}{l}\text { Salix babylonica "Tortuosa" } \\
\text { (Kovrčava vrba) }\end{array}$ & Salicaceae & $S$ & $\mathrm{~L}$ & Alohtona (K) & $\mathrm{E}$ & 1 \\
\hline $\begin{array}{l}\text { Salix fragilis } \mathrm{L} . \\
\text { (Krhka vrba) }\end{array}$ & Salicaceae & $\mathrm{S}$ & $\mathrm{L}$ & Autohtona & & 15 \\
\hline $\begin{array}{l}\text { Sorbus intermedia } \text { (Ehrh.) Pers. } \\
\text { (Skandinavska mukinja) }\end{array}$ & Rosaceae & $S$ & $\mathrm{~L}$ & Alohtona & $\mathrm{E}$ & 1 \\
\hline $\begin{array}{l}\text { Spiraea } x \text { vanhouttei (Briot) Zabel } \\
\text { (Vanhouteova suručica) }\end{array}$ & Rosaceae & G & $\mathrm{L}$ & Hibrid & & 9 \\
\hline $\begin{array}{l}\text { Styphnolobium japonicum (L.) Schott } \\
\text { (Japanska sofora) }\end{array}$ & Fabaceae & S & $\mathrm{L}$ & Alohtona & $\mathrm{E}$ & 1 \\
\hline $\begin{array}{l}\text { Syringa vulgaris } \mathrm{L} . \\
\text { (Obični jorgovan) }\end{array}$ & Oleaceae & $\mathrm{G} / \mathrm{S}$ & $\mathrm{L}$ & Alohtona & $\mathrm{E}$ & 1 \\
\hline $\begin{array}{l}\text { Tilia cordata Mill. } \\
\text { (Malolisna lipa) }\end{array}$ & Tiliaceae & $S$ & $\mathrm{~L}$ & Autohtona & & 8 \\
\hline $\begin{array}{l}\text { Tilia platyphyllos Scop. } \\
\text { (Velelisna lipa) }\end{array}$ & Tiliaceae & $S$ & $\mathrm{~L}$ & Autohtona & & 23 \\
\hline $\begin{array}{l}\text { Tilia tomentosa Moench } \\
\text { (Srebrnolisna lipa) }\end{array}$ & Tiliaceae & $S$ & $\mathrm{~L}$ & Autohtona & & 9 \\
\hline $\begin{array}{l}\text { Ulmus glabra "Pendula" } \\
\text { (Žalosni gorski brijest) }\end{array}$ & Ulmaceae & $\mathrm{G}$ & $\mathrm{L}$ & Autohtona (K) & & 1 \\
\hline $\begin{array}{l}\text { Ulmus laevis Pall. } \\
\text { (Brijest vez) }\end{array}$ & Ulmaceae & S & $\mathrm{L}$ & Autohtona & & 1 \\
\hline $\begin{array}{l}\text { Viburnum lantana } \mathrm{L} . \\
\text { (Crna hudika) }\end{array}$ & Caprifoliaceae & G & $\mathrm{L}$ & Autohtona & & 9 \\
\hline $\begin{array}{l}\text { Viburnum opulus L. } \\
\text { (Crvena hudika) }\end{array}$ & Caprifoliaceae & G & $\mathrm{L}$ & Autohtona & & 2 \\
\hline $\begin{array}{l}\text { Vinca major "Variegata" } \\
\text { (Velika pavenka) }\end{array}$ & Apocynaceae & $\mathrm{Pu}$ & $\mathrm{V}$ & Autohtona & & 23 \\
\hline \multicolumn{6}{|c|}{ LILIOPSIDA (MONOCOTYLEDONES) } & kom \\
\hline $\begin{array}{l}\text { Ruscus aculeatus } \mathrm{L} . \\
\text { (Bodljikava veprina) }\end{array}$ & Ruscaceae & $\mathrm{G}$ & $\mathrm{V}$ & Autohtona & & 3 \\
\hline $\begin{array}{l}\text { Yucca gloriosa } \mathrm{L} . \\
\text { (Veličanstvena juka) }\end{array}$ & Agavaceae & G & $\mathrm{V}$ & Alohtona & $\mathrm{E}$ & 8 \\
\hline
\end{tabular}




\section{Analiza flore}

Taksonomskom analizom dendroflore Gradskog parka u Bihaću (Tablica 1.) obuhvaćeno je 80 svojti s 663 jedinke. Dominiraju kritosjemenjače (66 svojti; $83 \%$ ), među kojima su dvosupnice (78; 97 \%), znatno zastupljenije nego jednosupnice (2; $3 \%$ ), a svrstane su u 30 porodica. Golosjemenjače su zastupljene s 14 svojti (17\%). S najvećim brojem svojti ističe se porodica Rosaceae (10 svojti; $13 \%$ ) od ukupno 80 svojti.

Analiza flore obzirom na tip habitusa (Erhardt et al., 2002) pokazuje dominaciju stabala (45 svojti; 56 $\%$ ), zatim slijede grmovi (32 svojte; $40 \%$ ), penjačice (2 svojte; $3 \%$ ) i puzavice (1 svojta; $1 \%$ ). Listopadne svojte $(60 ; 75 \%)$ su zastupljenije od vazdazelenih $(20 ; 24 \%)$ i zimzelenih $(1 ; 1 \%)$.

Najbrojnija svojta u parku je hibridna platana Platanus $x$ hispanica Münch s 115 jedinki.

Prema geografskom podrijetlu alohtone svojte $(42 ; 52 \%)$ su zastupljenije od autohtonih $(35 ; 44 \%)$ i hibrida (alohtonih svojti) (3; $4 \%)$.

Od 42 determinirane alohtone svojte u invazivne spadaju 3 svojte (7\%), dok u egzote spada 39 svojti (93\%) od ukupnog broja alohtonih svojti.

Od 80 zabilježenih svojti, u kultivare spada 15 svojti (19\%), a u hibride (alohtonih svojti) 3 svojte (4 \%)

\section{Parkovna dendroflora u oblikovanju Gradskog parka u Bihaću}

Slika 2. Pogled-1. na Gradski park

(Foto: Emir Delić, 2018).

Figure 2. View-1 at City park

(Foto: Emir Delić, 2018).

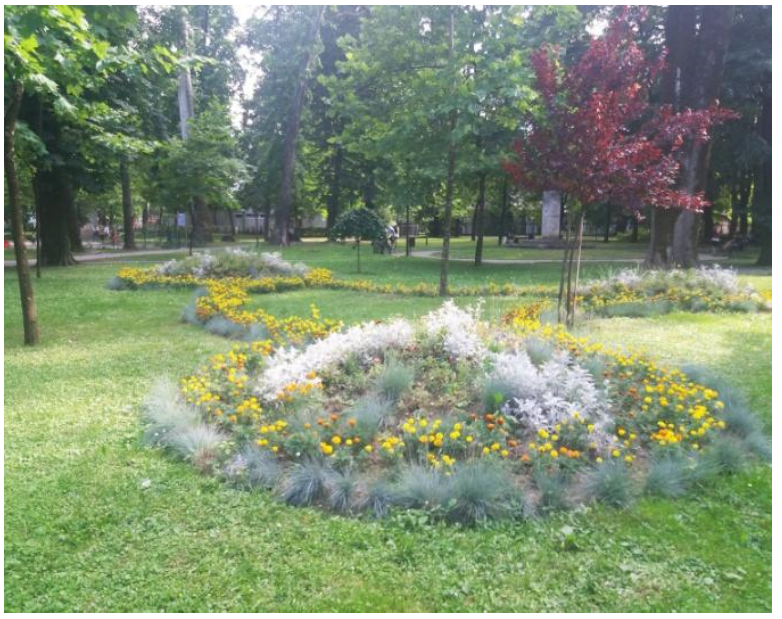

Slika 3. Pogled-2. na Gradski park (Foto: Emir Delić, 2018).

Figure 3. View-2 at City park (Foto: Emir Delić, 2018).

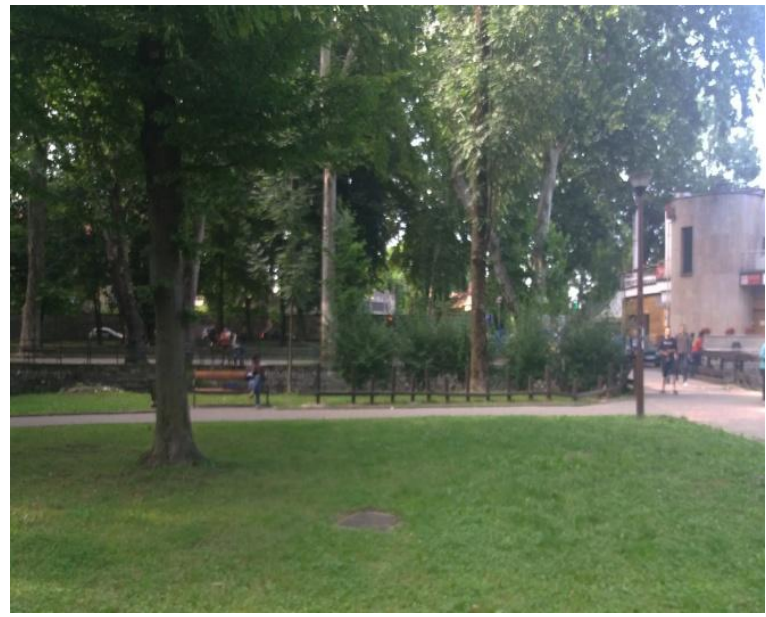

Gradski park u Bihaću vrlo je bogat dendrološkim svojtama. Tijekom terenskog istraživanja Delić (2016) utvrđeno je da Gradski park u Bihaću obiluje dendrološkim svojtama, njih čak 80 (s 663 jedinke), te spada u jedne od ljepših parkova u okruženju (Slike 2. i 3.). Drveće i grmlje uglavnom je 
dobrog zdravstvenog stanja i estetskog uklapanja u park. Međutim potrebna mu je revitalizacija. Mnoga stabla su već u dubokoj starosti, posebno platane i divlji kesteni, kojima se lome osušene grane i ogranci za vrijeme malo jačih vjetrova, te bi ih trebalo ukloniti, a na njihovo mjesto posaditi neke atraktivne dendro svojte: zanimljivog jesenskog izgleda (Quercus coccinea Münchh - grimizni hrast, kojem su listovi u jesen grimizno crvene boje ili Quercus palustris Münchh također s atraktivnim izrazito crvenim listovima u jesen), zimskog (Cornus sanguinea L. - svib, predlaže se posaditi nekoliko grmova sviba, čiji su izbojci u zimu krvavo-crvene boje i izrazito dekorativni), proljetnog (Cercis canadensis L. - kanadsko judino drvo, otporno na niske temperature, cvjeta u travnju, prije listanja s mnogobrojnim ljubičasto crvenim cvjetovima, koji se pojavljuju i po deblu i granama) i ljetnog (Weigela florida Bunge A. DC. - ružičasta vajgela, koja cvjeta od travnja do kolovoza).

Rasvjetni stupovi bi se mogli ukrasiti prelijepim japanskim (Wisteria floribunda) ili kineskim (Wisteria sinensis Sims Sweet) glicinijama, ili tekomom (Campsis radicans L. Seem. Ex Bureau). Ove vrlo dekorativne do $10 \mathrm{~m}$ visoke penjačice bi park podigle na viši nivo. Također bi se trebala dodati još po neka viseća forma (Pendula) bijelog duda Morus alba "Pendula" te neki vazdazeleni grm, koji dobro podnosi orezivanje koji bi se mogao formirati u atraktivne oblike (Ilex aquifolium L. - obična božikovina, šimšir (Buxus sempervirens L.). Navedene vrste bi unijele živost u park, te podiglo estetski izgled i doživljaj parka mnogim turistima i građanima. Na navedeni način bi se poboljšala i društvena uloga parka (građani bi više vremena provodili u parku). U parku se nalazi i nekoliko otrovnih primjeraka obične tise (Taxus baccata L.), odmah pored dječjeg igrališta, pa bi trebalo postaviti natpis "OTROVNA VRSTA!!!" kao svojevrsno upozorenje.

Pored nekih markantnijih stabala u parku (japanske trešnje (Prunus serrulata L.), hibridne platane (Platanus x hispanica Münchh), gorski javor (Acer pseudoplatanus L.), močvarni taksodij [Taxodium distichum (L.) Rich.], europska tisa (Taxus baccata L.), mogao bi se postaviti natpis s narodnim i latinskim imenom svojte, kako bi prolaznici znali o kojoj se svojti radi, što bi značajno doprinijelo edukaciji građana i estetskom izgledu ovog parka.

Ako bi se park uredio u skladu s navedenim smjernicama, što sigurno iziskuje i određena financijska sredstva, mnogim građanima, prolaznicima i turistima bi ostao dugo u sjećanju i poželjeli bi više vremena provoditi u njemu.

U parku je nedavno izgrađeno novo dječje igralište (Slika 4.), što ga je još više populariziralo i privuklo mnogo turista koji sa svojom djecom uživaju u blagodatima parka. Parkovna infrastruktura je u vrlo dobrom stanju, putovi i staze su uredni i neoštećeni, kao i klupe i kante za otpatke (Slika 5.). U parku je i rasvjeta dotrajala, slabo je osvijetljen te se pojedina mjesta nalaze u potpunom mraku, tako da nisu rijetki i neprihvatljivi oblici ponašanja i vandalizam. Unutar parka nalazi se nekoliko dekorativnih informacijskih "kućica", koje pružaju posjetiteljima informacije o parku; njegovom nastanku, pravilima ponašanja unutar parka, o rijeci Uni, a opisano je i pet najdekorativnijih i najuočljivijih svojti (Slika 6.). 
Slika 4. Novoizgrađeno dječje igralište (Foto: Emir Delić, 2018).

Figure 4. Newly built children's playground (Foto: Emir Delić, 2018).

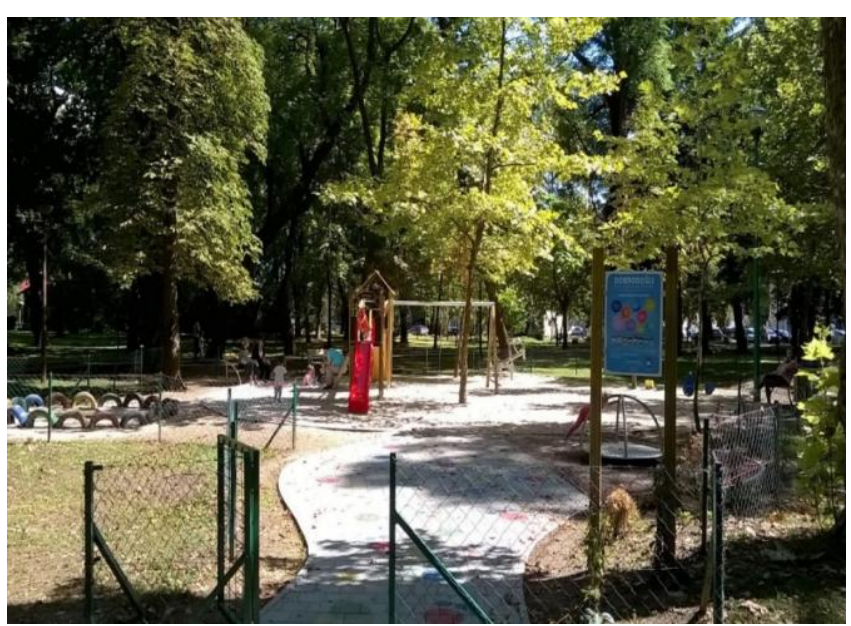

Slika 5. Mjesta za odmor (Foto: Emir Delić, 2018).

Figure 5. Places to rest (Foto: Emir Delić, 2018).

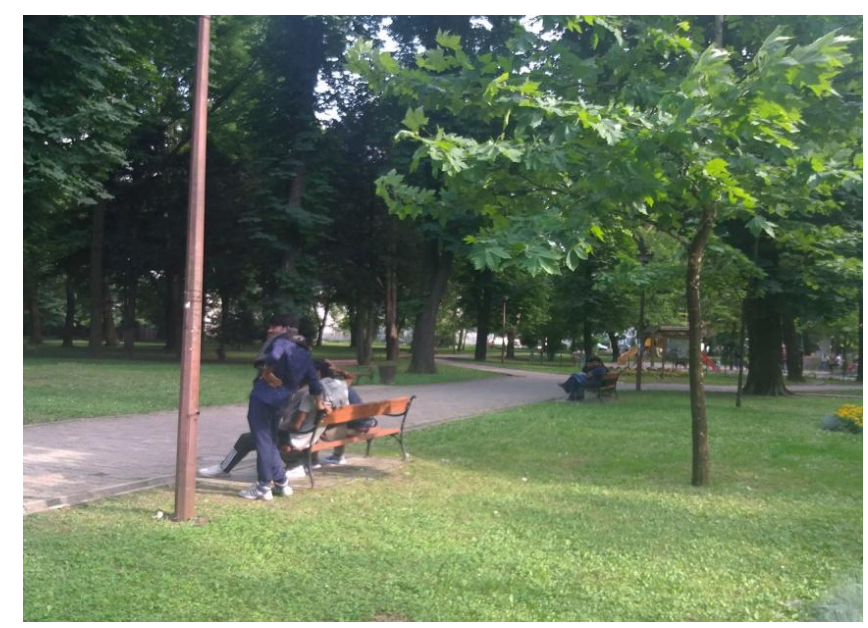

Slika 6. Informacijske "kućice" za turiste s zanimljivostima o parku (Foto: Emir Delić, 2018). Figure 6. Tourist information object (Foto: Emir Delić, 2018).

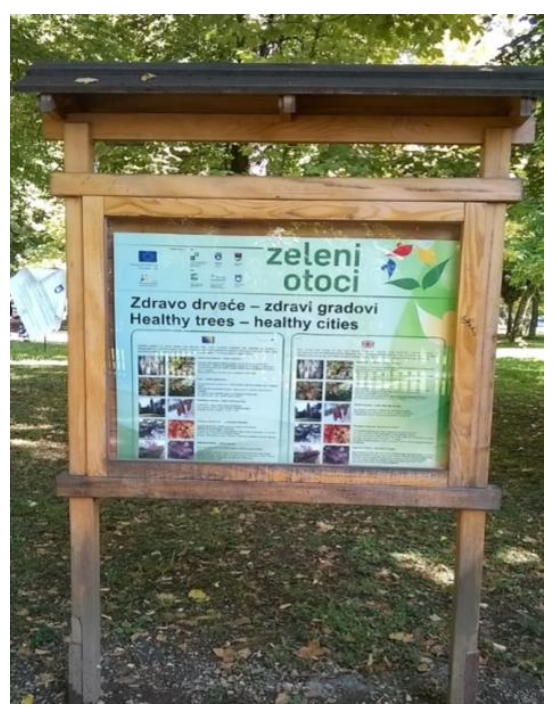




\section{Zaključak}

Tijekom florističkog istraživanja inventarizacije Gradskog parka u Bihaću ustanovljeno je sljedeće stanje: taksonomskom analizom dendroflore Gradskog parka u Bihaću obuhvaćeno je 80 svojti s 663 jedinke, gdje dominiraju kritosjemenjače (66 svojti; $83 \%$ ), a svrstane su u 30 porodica. S najvećim brojem svojti ističe se porodica Rosaceae (10 svojti; $13 \%$ ) od ukupno 80 svojti. Analiza dendroflore s obzirom na tip habitusa (Erhardt et al., 2002) pokazuje dominaciju stabala (45 svojti; $56 \%$ ). Listopadne svojte $(60 ; 75 \%)$ su zastupljenije od vazdazelenih i zimzelenih. Najbrojnija svojta u parku je hibrid Platanus $x$ hispanica Münchh sa 115 jedinki. Prema geografskom podrijetlu alohtone svojte (42; $52 \%)$ su zastupljenije od autohtonih $(35 ; 44 \%)$ i hibrida $(3 ; 4 \%)$. Od 42 determinirane alohtone svojte u invazivne spadaju 3 svojte (7\%), dok u egzote spada 39 svojti (93\%). Od 80 zabilježenih svojti, u kultivare spada 15 svojti (19\%), a u hibride (alohtonih svojti) 3 svojte (4\%). U pogledu krajobraznih vrijednosti Gradski park u Bihaću je veoma bogat dendrološkim svojtama, zabilježeno ih je čak 80 (s 663 jedinke), te on spada u jedne od ljepših parkova u okruženju. U Gradskom parku koji je podignut 1888. godine su najimpozantnije hibridne platane (Platanus x hispanica Münch), koje datiraju još iz doba austrougarske uprave, kao i stabla divljeg kestena (Aesculus hippocastanum L.). Međutim ovom parku je potrebna dodatna revitalizacija. U parku je i rasvjeta dotrajala, slabo je osvijetljen te se pojedina mjesta nalaze u potpunom mraku, tako da nisu rijetki i neprihvatljivi oblici ponašanja i vandalizam. Drveće i grmlje uglavnom je dobrog zdravstvenog stanja i estetskog uklapanja u park. Parkovna infrastruktura (klupe, spomenici, staze) su u vrlo dobrom stanju, te ih je potrebno redovno održavati.

\section{Zahvala}

Rad je izrađen u okviru izrade Završnog rada Emira Delića, BA šumarstva: "Inventarizacija i valorizacija dendroflore Gradskog parka u Bihaću", Univerzitet u Bihaću, Biotehnički fakultet, (2016).

\section{Literatura}

Anonymous (2016). Geografski položaj. Posjećeno 07. 03. 2016 na mrežnoj stranici Grada Bihaća: http://bihac.org/bs/geografski-polozaj.

Bihać kroz vrijeme (2010). Kratka historija Bihaća \#2. Posjećeno 07. 03. 2016 na Bihać kroz vrijeme mrežnoj stranici: https://bihackrozvrijeme.wordpress.com/2010/12/12/kratka-historija-bihaca-2.

Čomić, R., Šumantić, N., Čomić, D., Gudurić, I., Stankov J. (2009). Zaštita urbanih šuma i zelenih površina. Banja Luka: Akademsko udruženje "Eko logic".

Delić, E. (2016). Inventarizacija i valorizacija dendroflore Gradskog parka u Bihaću, završni rad, Univerzitet u Bihaću, Biotehnički fakultet. 
Domac, R. (1994). Flora Hrvatske. Zagreb: Školska knjiga.

Dorbić, B., Temim, E. (2014). Utjecaj zelenila i parkovnog modernizma na društveni život stanovnika Šibensko-kninske županije. Agronomski glasnik 76(6), 327-348.

Erhardt, W., Gotz, E., Bodeker, N., Seybold, S. (2002). Zander, Handworterbuch der Pflanzennamen. Stuttgart: Eugen Ulmer.

Idžojtić, M. (2005). Listopadno drveće i grmlje u zimskom razdoblju. Zagreb: Sveučilište u Zagrebu, Šumarski fakultet.

Idžojtić, M. (2009). Dendrologija-List. Zagreb: Sveučilište u Zagrebu, Šumarski fakultet.

Idžojtić, M. (2013). Dendrologija - cvijet, češer, plod, sjeme. Zagreb: Sveučilište u Zagrebu, Šumarski fakultet.

Karavla, J. (2006). Dendrološke karakteristike zelene potkove grada Zagreba s prijedlogom obnove njezinoga istočnoga dijela. Šumarski list 30(1-2), 31-40.

Ljujić-Mijatović, T., Živojević, S., Bečić, B. (2010). Identifikacija, valorizacija i zaštita parkovne baštine u periodu Austro-Ugarske u Bosni i Hercegovini. Glasnik Zaštite Bilja 33(6), 18-25.

Mlinar, I., Trošić, M. (2004). Parkovi zagrebačkih stambenih naselja izgrađenih između dva svjetska rata. Prostor: znanstveni časopis za arhitekturu i urbanizam 12, 1(27), 31-44.

Natura Jadera (Javna ustanova za upravljanje zaštićenim dijelovima prirode na području Zadarske županije) (2014). Plan upravljanja "Zelenim otocima" 2015. - 2020. Preuzeto 17. 05. 2016. s mrežne stranice Nature Jadera: http://natura-jadera.com/Dokumenti/plan_upravljanja_zelenim_otocima_20152020.pdf.

Nikolić, T. (ur.) (2012). Flora Croatica baza podataka / Flora Croatica Database. Botanički zavod s Botaničkim vrtom, Prirodoslovno-matematički fakultet, Sveučilište u Zagrebu. Dostupno na: http://hirc.botanic.hr/fcd.

Poljak, I., Idžojtić, M., Zebec, M. (2011). Dendroflora zološkog vrta grada Zagreba. Šumarski list 35(5-6), 269-281.

Rauš, Đ. (1969). Autohtona i alohtona dendroflora šire okolice Vukovara. Šumarski list (5-6), 185209.

Redžić, S., Barudanović, S., Radević, S. (ur.) (2008). Bosna i Hercegovina - zemlja raznolikosti. Monografija. Pregled i stanje biološke i pejzažne raznolikosti Bosne i Hercegovine, Prvi izvještaj BiH za CBD. Sarajevo: Federalno ministarstvo okoliša i turizma. 
E. Delić, Jasnica Medak, Azra Bakrač, Subha Džafić, B. Dorbić, Berina Muhović / Dendroflora Gradskog parka u Bihaću / Glasilo Future (2018) 1 (3) 01-14

Stupar, V. (2009). Dendroflora parka "Univerzitetski grad" u Banjoj Luci. Glasnik Šumarskog fakulteta Univerziteta u Banjoj Luci 10, 25-42.

Šilić, Č. (1990). Ukrasno drveće i grmlje. Sarajevo: Svjetlost.

Šilić, Č. (2005). Atlas dendroflore (drveće i grmlje) Bosne i Hercegovine. Čitluk: Matica hrvatska.

Španjol, Ž., Barčić, D., Rosavec, R., Dorbić, B. (2011). Biološko-ekološko i prostorno vrednovanje zaštićenih prirodnih vrijednosti u županijama sjeverozapadne Hrvatske. Šumarski list 135(1-2), 51-61.

Tutin, T. G., Heywood, V. T., Burges, N. A., Moore, D. M., Valentine, D. H., Walters, S. M., Webb, D. A. (eds.). (1964-1980). Flora europea 1-5. Cambridge: Cambridge University Press.

Vidaković, M., Franjić, J. (2004). Golosjemenjače. Zagreb: Sveučilište u Zagrebu, Šumarski fakultet.

Vlahović, I., Karlović, K. (2013). Otrovne i alergene biljne vrste u školskim vrtovima grada Samobora. Agronomski glasnik 75(2-3), 107-116.

Walters, S. M., Brady, A., Brickell, C. D., Cullen, J., Green, P. S., Lewis, J., Matthews, V. A., Webb, D. A., Yeo, P. F., Alexander, J. C. M. (eds.). (1984-1986). The European Garden Flora, I-II. Cambridge: Cambridge University Press.

Walters, S. M., Brady, A., Brickell, C. D., Cullen, J., Green, P. S., Lewis, J., Matthews, V. A., Webb, D. A., Yeo, P. F., Alexander, J. C. M. (eds.). (1989). The European Garden Flora, III. Cambridge: Cambridge University Press.

Židovec, V., Karlović, K. (2005). Primjena autohtonog bilja u uređenju gradskog prostora. Agronomski glasnik 67(2-4), 151-158.

Primljeno: 04. srpnja 2018. godine

Prihvaćeno: 14 . kolovoza 2018. godine
Received: July 04, 2018

Accepted: August 14, 2018 